\title{
Clinical Diagnosis of Chorioretinitis Sclopetaria in a Patient Presenting without a History of Trauma
}

\author{
Travma Öyküsü Olmayan bir Hastada Koryoretinitis Sklopeterya'nın Klinik Tanısı
}

\author{
Yaran Koban ${ }^{1}$, Orhan Ayar ${ }^{2}$, Mustafa Koç3 ${ }^{3}$ Sibel Karayol ${ }^{4}$
}

${ }^{1}$ Kafkas University Faculty of Medicine, Department of Ophthalmology, Kars, Turkey

${ }^{2}$ Bülent Ecevit University Faculty of Medicine, Department of Ophthalmology, Zonguldak, Turkey

${ }^{3}$ Ulucanlar Eye Training and Research Hospital, Department of Ophthalmology, Ankara, Turkey

${ }^{4}$ Harran University Faculty of Medicine, Departmant of Radiology, Kars, Tutkey

\section{ABSTRACT}

Chorioretinitis sclopetaria is a rare and unique manifestation of ocular trauma caused by high-velocity objects that pass adjacent to, but do not penetrate the globe. In these patients, anamnesis is very helpful for diagnosis and it is not expected that a patient could completely forget the trauma as these traumas are generally severe. Diagnosis can be difficult in the case of patients who do not state trauma in anamnesis as in our case. It is crucial to recognize the pathognomonic fundus findings in this rarely seen condition because these findings are invaluable in the absence of history of trauma. In this case report, we describe a case of chorioretinitis sclopetaria who was injured with a ball-bearing (BB) gun in childhood and did not realize.

Key Words: Chorioretinitis, choroid injuries, sclopetaria, trauma.

Received: 03.25 .2018

Accepted:10.04.2018

\section{ÖZET}

Koryoretinitis sklopeterya, globa yakın geçen ancak globu perfore etmeyen yüksek hızlı nesnelerin neden olduğu oküler travmalara bağlı gelişen nadir bir klinik tablodur. Bu hastalarda hikaye tanı koymada oldukça yardımcıdır ve bu travmaların genellikle şiddetli olmasından dolayı hastanın geçirilen travmayı tamamen unutması beklenmemektedir. Bizim vakamızda olduğu gibi, eğer hastalar geçirdikleri travmayı hikayede belirtmezlerse tanı koymak zor olabilir. Nadir bir durum olan koryoretinitis sclopeteryanın tanı koydurucu göz dibi bulguları özellikle oküler travma hikayesinin olmadığı bu durumlarda doğru teşhisde çok değerlidir. Bu olgu sunumunda, koryoretinitis sclopetaria olgusu tarif edilmekte, patofizyolojik mekanizması, klinik bulguları, olası komplikasyonları ve tedavi seçenekleri tartışılmaktadır.

Anahtar Sözcükler: Koryoretinitis, koroid yaralanmaları, sklopeterya, travma.

Geliş Tarihi: 25.03 .2018

Kabul Tarihi:04.10.2018

\section{INTRODUCTION}

Ocular trauma is one of the leading causes of unilateral visual loss in children and young adults. Non-penetrating trauma or closed globe injury where the corneoscleral wall of the globe remains intact may also be associated with various vitreoretinal complications such as choroidal rupture, optic nerve injury, macular hole, and retinal detachment (1).

Chorioretinitis sclopetaria is a rare clinical presentation resulting from trauma caused by a high-velocity projectile object passing adjacent to or through the orbit without penetrating the globe $(2,3)$. The pathophysiological mechanism of the injury is caused by the energy release resulting from the high speed of the projectile when reaching the orbital cavity and passing close to the eyeball in its path (4). The descriptive term "chorioretinitis" initially referred to white areas seen on fundus examination that were thought to be inflammatory, but it is clear that the chorioretinal rupture is a result of trauma and not an inflammatory process $(3,4)$. Despite widespread injury to the retina, retinal pigment epithelium and choroid, the retina often remains attached even without any treatment, as a result of chorioretinal scarring and the subsequent adhesion between the retina and underlying tissues (5).

In this case report, we describe a rare case of chorioretinitis sclopetaria who was injured with a ball-bearing (BB) gun in childhood and did not realize and discuss the clinical findings and treatment options.

\section{CASE REPORT}

A 22-year-old male was referred to our clinic because of low vision in the right eye that was established during a military health and welfare inspection. He did not notice the lack of vision and ophthalmologic examination was not previously performed. Upon examination, the uncorrected visual acuity (VA) in the right eye was finger count at 1.5 meters and 10/10 in the left eye with normal ocular motility. The relative afferent pupillary defect (RAPD) was positive in the right eye. The intraocular pressure (IOP) measurements with Goldmann applanation tonometry were $15 \mathrm{mmHg}$ in the right eye and $14 \mathrm{mmHg}$ in the left eye. Anterior segment examination of the right and left eyes was normal. Fundus examination of the right eye revealed hyperplasia of the retina pigment epithelium, epiretinal membrane and subretinal membrane, extending from the macula and optic nerve to the peripheral retina (Figure 1). Intraretinal-preretinal hemorrhage, macular scar, macular hole, retinal detachment/hole, and atrophy-hemiatropy of the optic disc were not present. Fundus examination of the left eye was normal. Optical coherence tomography of the right macula revealed hyper-reflectivity from the retinal pigment epithelium (RPE) hyperplasia and loss of outer retinal layers adjacent to the RPE hyperplasia (Figure 2). 


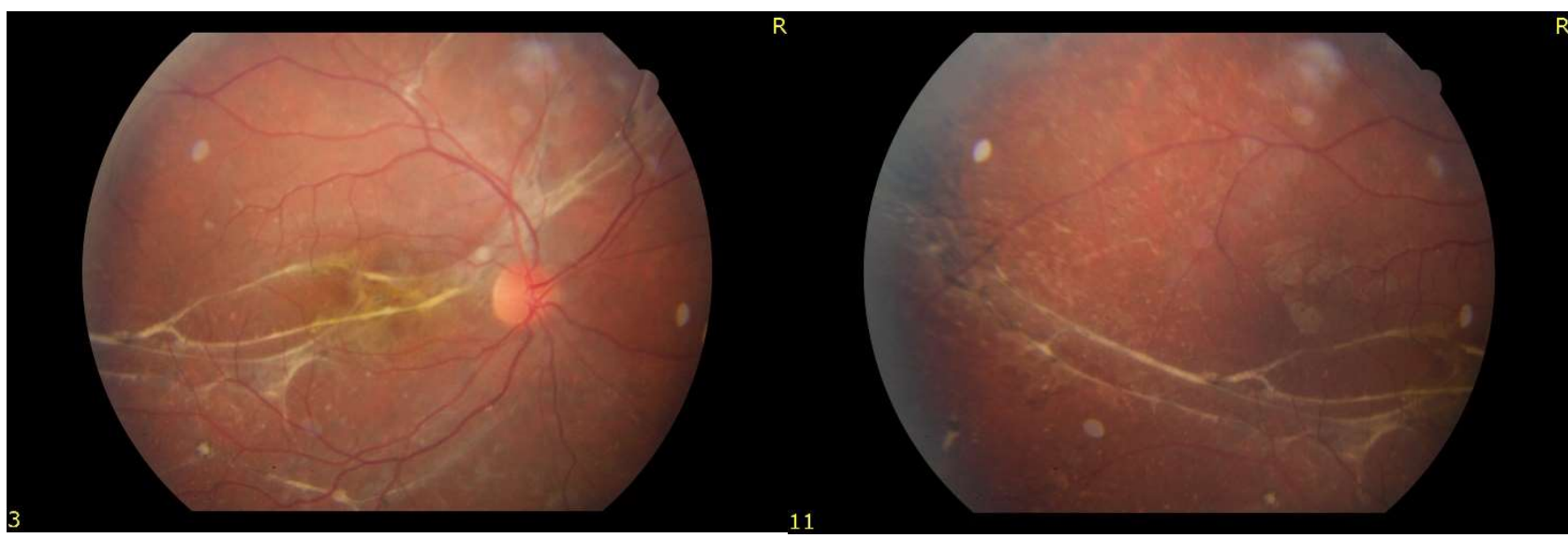

Figure 1: a) Color fundus photograph of the right eye showing macular pre-retinal and subretinal gliotic membrane extending from the macula and optic nerve to the peripheral retina. b) The lesions of the posterior pole are contiguous with the peripheral lesions. Note the irregular pigmentary disturbances and the pre-retinal gliotic membrane.

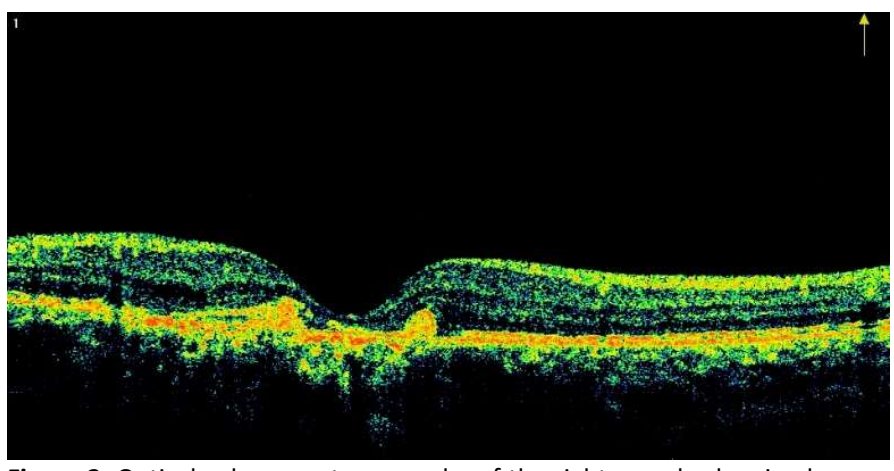

Figure 2: Optical coherence tomography of the right macula showing hyperreflectivity from the retinal pigment epithelium hyperplasia.

The patient's past history was negative for any medical or surgical diseases. When asked about trauma, his parents recalled that the patient applied to the emergency service with conjunctival hemorrhage complaint nearly 15 years ago. Topical antibiotic therapy was started with 2 weeks duration and conjunctival hemorrhage recovered after this treatment. Based on the history and ophthalmological examination findings, a diagnosis of chorioretinitis sclopetaria was suspected and posteroanterior and right lateral radiographs of the orbit were performed to confirm the diagnosis. X-rays revealed an intraorbital foreign body in the right orbit, and this was confirmed on computerized tomography (Figure 3). It was thought that he had been accidentally shot with a BB gun, when the computed tomography (CT) images were analyzed. No surgical intervention was undertaken. The patient was warned about the potential risks of the metal foreign body adjacent to the optic nerve in the orbital apex especially during magnetic resonance imaging (MRI).

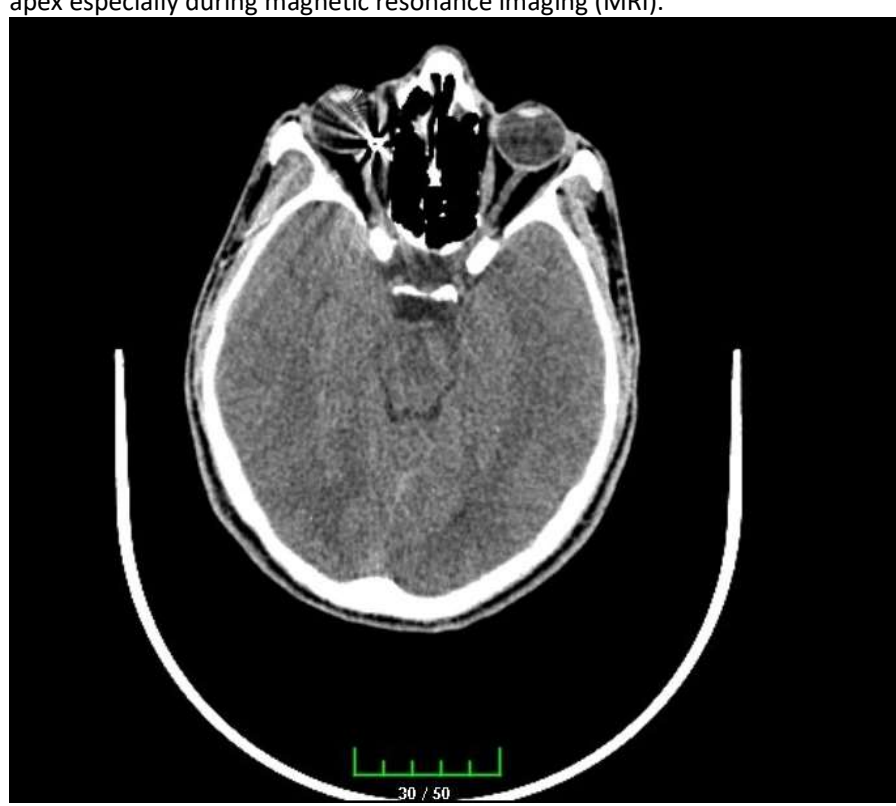

Figure 3: Computerized tomography showing a retrobulbar foreign body in the right orbit.

\section{DISCUSSION}

Chorioretinits sclopetaria may be defined as a full-thickness break of the choroid, Bruch's membrane, and retina as a result of a high-velocity missile striking or passing adjacent to, but not penetrating, the globe (5). Two mechanisms have been considered here: damage adjacent to the pathway of the missile is responsible for the direct injury, and the shock waves transmitted to the globe cause the indirect injury. The extent of ocular damage is determined by the missile's proximity to the globe, its velocity and its size(6).

There are various eye problems accompanying sclopetaria at presentation, such as lid laceration, canthus laceration, subconjunctival hemorrhage, conjunctival laceration, hyphema, vitreous hemorrhage, subretinal and macular hemorrhage, hemorrhage on optic disc, retinal edema, choroidal and retinal ruptures, optic nerve transaction and transection of the rectus muscle $(2,5-8)$. In the acute phase of chorioretinitis sclopetaria, the disease is easily diagnosed due to clear findings, intraorbital foreign body and history of trauma, while in the advanced period in situations where the patient forgets trauma on anamnesis, hides trauma due to family or patient legal reasons or due to memory loss linked to the effect of trauma posterior segment, findings carry great importance. Recognizing these pathognomonic fundus findings can ensure the clinician suspects chorioretinitis sclopetaria in spite of the lack of trauma in patient history.

Histopathologic studies about sclopetaria show partial loss of the nerve fiber and ganglion cell layers in the macula, temporal peripapillary and macular loss of photoreceptors with hypertrophy and hyperplasia of the RPE, an epiretinal membrane, and defects in Bruch's membrane, choroid, and retina. With time, these structures are replaced by a loose and dense fibrous connective tissue (9). Besides, chorioretinitis sclopetaria is accompanied by bare sclera, typically. Scleral attachments to the choroid are practically nonexistent between the ora serrata and the equator and the choroid is under constant tension and will retract, exposing the bare sclera when cut (4). In the late period, a sharply demarcated area in the peripheral retina of blotches of pigment proliferation along with fibrosis, bare sclera, pale optic disc, macular pigmentary changes and retinal and choroidal tears is suggestive of chorioretinitis sclopetaria (6). Also, macular scar, choroidal neovascularization and fibrovascular proliferation are late complications developed in response to the damage to Bruch's membrane (10).

The risk of retinal detachment following chorioretinitis sclopetaria is low and based on the proliferation of fibrous tissue, which causes firm adherence of retina and choroid to the sclera, along with the typically intact posterior hyaloid frequently seen in young patients, which prevents fluid access to the subretinal space and lowers the risk of subretinal neovascular membrane formation and acute retinal detachment $(11,12)$. Ahmadabadi et al. published one of the largest chorioretinitis sclopetaria study series, examining 13 affected eyes in 13 patients. Among these 13 cases of chorioretinitis sclopetaria, only one patient had developed acute retinal detachment; the retina remained attached in the other patients throughout the follow-up period (6).

In the acute phase of chorioretinitis sclopetaria, hemorrhages (vitreous, retinal and/or subretinal), and choroidal and retinal ruptures can be seen, besides retinal edema (11). For differential diagnosis, ruptured globe, intraocular foreign body, commotio retina, choroidal rupture, and optic nerve avulsion should be considered. Ruptured globe and intraocular foreign body are excluded by clinical exam, B-scan ultrasonography, and computed tomography of the eye and orbit (13). It is known that the choroid ruptures are associated with blunt trauma, either by direct or indirect mechanism. Choroid, Bruch's membrane and RPE injury are described. 
Neurosensory retina is not involved, usually white or yellow crescent-shaped subretinal streaks are seen usually concentric to the optic nerve. Subretinal neovascular membrane may develop. Injury to Bruch's membrane increase the risk of subretinal neovascularization development (10). Retinal and macula whitening with a cherry aspect (Berlin edema) have also been reported after eye injuries, a condition that is known as commotio retinae. Both can appear in chorioretinitis sclopetaria, as it also has a blunt component in its pathophysiology. In optic nerve avulsions, due to the accompanying anterior segment pathologies and appearance of optic nerve and retina with vitreous hemorrhage, diagnosis is obstructed. IN these types of cases, imaging methods like electrodiagnostic tests, B-scan ultrasonography, CT or MR may be beneficial (13).

The late complication of the chorioretinitis sclopetaria is the same as choroidal rupture in other situations, i.e., the possibility of developing neovascularization from the choroid and fibrovascular proliferation. This occurs in 25 to $50 \%$ one year after the choroid ruptures (10).

\section{CONCLUSION}

Chorioretinitis sclopetaria is a rare manifestation of ocular trauma and has no specific treatment. In the acute phase, a detailed examination and recognizing the pathognomonic findings allow immediate diagnosis. As in our case, if patients do not state trauma in the anamnesis, accurate diagnosis can be difficult after a few years. After intense findings in the acute period regress, the appearance of the fundus should still contain findings reminiscent of severe trauma. It is important and necessary to recognize this characteristic fundus appearance, because an accurate diagnosis can prevent unwarranted surgical intervention

\section{Conflict of interest}

No conflict of interest was declared by the authors.

\section{REFERENCES}

1. Pieramici DJ. Vitreoretinal trauma. Ophthalmol Clin North Am 2002;15:225-34.

2. Mohammadpour $M$, Soheilian $M$. Concomitant optic nerve transection and chorioretinitis sclopetaria. BMC Ophthalmol 2005;5:29.

3. Fraser EJ, Haug SJ, McDonald HR. Clinical presentation of chorioretinitis sclopetaria. Retin Cases Brief Rep. 2014;8:257-9.

4. Papakostas TD, Yonekawa Y, Skondra D, Vavvas DG. Traumatic chorioretinal rupture (sclopetaria). Int Ophthalmol Clin. 2013;53:11925.

5. Beatty S, Smyth K, Au Eong KG, Lavin MJ. Chorioretinitis sclopetaria. Injury 2000;31:55-60

6. Ahmadabadi MN, Karkhaneh R, Roohipoor R, Tabatabai A, Alimardani A. Clinical presentation and outcome of chorioretinitis sclopetaria: a case series study. Injury 2010;41:82-5.

7. MacKenzie K, Verity D, Ali N. Traumatic transection of the lateral rectus muscle with chorioretinitis sclopetaria. Strabismus 2015;23:36-8.

8. Ahmadabadi MN, Karkhaneh R, Valeshabad AK, Tabatabai A, Jager MJ, Ahmadabadi EN. Clinical presentation and outcome of perforating ocular injuries due to BB guns: $A$ case series. Injury 2011;42:492-5.

9. Dubovy SR, Guyton DL, Green WR. Clinicopathologic correlation of chorioretinitis sclopetaria. Retina 1997;17:510-20.

10. Artunay $O$, Rasier R, Yuzbasioglu E, Sengül A, Bahcecioglu H.. Intravitreal bevacizumab injection in patients with choroidal neovascularization due to choroid rupture after blunt-head trauma. Int Ophthalmol 2009;29:289-91.

11. Richards RD, West CE, Meisels AA. Chorioretinitis sclopetaria. Am J Ophthalmol 1968;66:852-60.

12. Martin DF, Awh CC, McCuen BW, Jaffe GJ, Slott JH, Machemer R. Treatment and pathogenesis of traumatic chorioretinal rupture (sclopetaria). Am J Ophthalmol 1994;117:190-200.

13. Carlos A. Medina, Justin H. Townsend, Arun D. Singh. Manual of Retinal Diseases: A Guide to Diagnosis and Management. 1th ed. Springer International Publishing, Switzerland. pp. 25-28. 